\title{
PENGARUH HARMONISA ARUS AKIBAT PENGGUNAAN BEBAN NON- LINIER TERHADAP HASIL PENGUKURAN kWhmeter ANALOG
}

\author{
I Made Wiwit Kastawan ${ }^{1 *}$, Gilang Pamungkas ${ }^{2}$ \\ ${ }^{1,2}$ Program Studi D-III Teknik Konversi Energi, Jurusan Teknik Konversi Energi, Politeknik Negeri Bandung, \\ Jalan Gegerkalong Hilir, Ciwaruga, Kabupaten Bandung Barat, Jawa Barat. \\ *Penulis korespondensi: wiwit.kastawan@polban.ac.id
}

\begin{abstract}
ABSTRAK
Penggunaan sumber tegangan non-sinusoidal atau beban non-linier pada sistem kelistrikan berdampak pada terbangkitkannya gelombang harmonisa arus. Gelombang harmonisa arus dapat mengakibatkan berbagai masalah, salah satunya adalah terjadinya kesalahan pada berbagai alat ukur yang terpasang pada sistem kelsitrikan tersebut. Dalam tulisan ini akan dibahas pengaruh gelombang harmonisa arus yang muncul sebagai akibat penggunaan beban-beban non-linier terhadap keakuratan hasil pengukuran konsumsi energi listrik oleh kWhmeter analog. Analisisnya dilakukan berdasarkan data yang diperoleh melalui pelaksanaan dua uji laboratorium berbeda yaitu pengukuran konsumsi energi listrik dengan beban linier (yang tidak menghasilkan gelombang harmonisa arus) dan pengukuran konsumsi energi listrik dengan beban non-linier (yang menghasilkan gelombang harmonisa arus dengan tingkat distorsi (total harmonic distortion, disingkat THD) berbeda. Hasil pengukuran konsumsi energi listrik dengan kWhmeter analog dan Power Quality Analyser (PQA) untuk masing-masing uji laboratorium akan dibandingkan untuk melihat perbedaannya dengan hasil pengukuran oleh PQA sebagai acuan. karena PQA memiliki kemampuan untuk pengukuran true rms berbagai besaran listrik yang mengandung gelombang harmonisa. Analisis terhadap data uji laboratorium menunjukkan bahwa harmonisa memiliki dampak atau pengaruh terhadap kesalahan pengukuran pemakaian energi oleh kWhmeter analog. Meski tidak meningkat secara signifikan namun semakin tinggi kandungan harmonisa arus maka akan semakin tinggi pula kesalahan pengukuran pemakaian energi listrik oleh $\mathrm{kWhmeter}$ analog. Lebih jauh, pengaruh harmonisa terhadap kesalahan pengukuran pemakaian energi oleh $\mathrm{kWhmeter}$ analog lebih signifikan untuk sistem kelistrikan tiga-fasa jika dibandingkan dengan sistem kelistrikan satu-fasa
\end{abstract}

Kata Kunci: beban, harmonisa, kWhmeter, linier, non-linier, PQA.

\section{Pendahuluan}

Munculnya gelombang harmonisa arus pada suatu sistem atau jaringan kelistrikan merupakan salah satu permasalahan kualitas daya yang banyak mendapat perhatian dalam beberapa tahun terakhir, khususnya saat penggunaan konverter daya semakin banyak dan populer. Perkembangan signifikan teknologi konverter daya telah mendorong berkembangnya penggunaan alat-alat listrik (beban) yang lebih sederhana dan kompak, murah serta efisien seperti komputer (laptop/personal computer (PC)), smartphone, lampu hemat energi, TV LED, air conditioning (AC) dengan penggerak inverter dan lain sebagainya [1]-[5]. Semakin populernya pemanfaatan sumber-sumber energi primer terbarukan seperti angin dan matahari, juga didorong dan didukung oleh perkembangan signifikan teknologi konverter daya ini [6]. Namun harus dapat dipahami juga bahwa banyaknya penggunaan konverter daya pada sistem kelistrikan telah memicu munculnya permasalahan gelombang harmonisa arus karena operasi on-off dari saklar-saklar statis konverter daya menghasilkan gelombang tegangan atau arus non-sinusoidal [7]. Gelombang harmonisa arus pada sistem kelistrikan dapat diakibatkan oleh arus pada beban non-linier yang menghasilkan arus di sisi sumber dengan bentuk nonsinusoidal [8], [9]. Contoh dari beban-beban non-linier ini adalah alat-alat listrik yang menggunakan berbagai jenis konverter daya yang telah disebutkan di atas.

Untuk sektor rumah tangga, beban non-linier yang banyak digunakan adalah komputer, pencatu daya baterai untuk laptop dan smartphone, lampu hemat energi, TV LED serta AC dan kulkas dengan inverter. Sementara untuk sektor industri dan gedung perkantoran, beban non-linier yang memiliki kontribusi besar terhadap munculnya gelombang harmonisa arus 
pada sistem kelistrikan adalah variable speed drive, disingkat VSD, sebagai penggerak motor-motor listrik arus bolak-balik di industri. Perangkat VSD ini banyak digunakan sebagai penggerak motor listrik untuk pompa dan kipas karena penggunaannya dapat mengurangi konsumsi energi listrik industri secara signifikan [1], [2], [10]. Keseluruhan beban non-linier ini pada dasarnya menggunakan penyearah dioda (satufasa atau tiga-fasa) pada sisi sumber atau masukannya [7]. Kerja dari penyearah dioda inilah yang sejatinya akan mengakibatkan muncul gelombang arus nonsinusoidal yang mengandung banyak harmonisa yang ditunjukkan oleh nilai persentasenya THD-nya yang tinggi.

\section{Gelombang Harmonisa dan Dampak Buruk Terhadap Sistem Kelistrikan}

Gelombang tegangan atau arus yang bersifat periodik namun memiliki bentuk non-sinusoidal merupakan gelombang tegangan atau arus yang mengandung harmonisa. Semakin jauh bentuk gelombang tegangan atau arus tersebut dari bentuk gelombang sinosuidal murni maka semakin tinggi kandungan harmonisanya. Oleh karenanya gelombang harmonisa dapat dinyatakan sebagai komponen distorsi dari bentuk gelombang dasar atau fundamental sinusoidal yang memiliki frekuensi kelipatan bulat dari frekuensi fundamental gelombang tersebut. Jumlah nilai efektif dari seluruh gelombang harmonisa tersebut yang dipersentasekan terhadap nilai efektif gelombang fundamentalnya disebut sebagai THD. Secara matematis, THD tegangan $\left(\mathrm{THD}_{\mathrm{V}}\right)$ dan arus $\left(\mathrm{THD}_{\mathrm{I}}\right)$ dinyatakan oleh persamaan (1) dan (2) berikut ini [7].

$$
\begin{gathered}
T H D_{V}=\frac{\sqrt{\sum_{n=2}^{\infty} V_{(n)}^{2}}}{V_{(1)}} \\
T H D_{I}=\frac{\sqrt{\sum_{n=2}^{\infty} I_{(n)}^{2}}}{I_{(1)}}
\end{gathered}
$$

Jika mengacu pada SNI 571-2001 maka standar untuk $\mathrm{THD}_{\mathrm{V}}$ dan $\mathrm{THD}_{\mathrm{I}}$ pada sistem kelistrikan masing-masing adalah kurang dari atau sama dengan 5\% dan $10 \%$.

Harmonisa, khususnya harmonisa arus, yang dibangkitkan oleh beban-beban non-linier dapat memberi dampak buruk terhadap sistem kelistrikan. Secara umum dampak buruk dari gelombang harmonisa ini dapat dikelompokkan menjadi dampak terhadap peralatan-peralatan daya listrik dan alat ukur yang terpasang pada sistem kelistrikan serta dampak terhadap sistem kelistrikan itu sendiri. Dampak buruk terhadap peralatan-peralatan daya listrik diantaranya meliputi dampak terhadap kapasitor, transformator daya serta motor dan generator listrik. Gelombang harmonisa mempengaruhi kapasitor secara signifikan akibat berkurangnya nilai reaktansi kapasitif untuk gelombang-gelombang harmonisa frekuensi tinggi. Untuk generator dan motor listrik, gelombang harmonisa berdampak buruk terhadap meningkatnya arus belitan yang bermuara pada bertambahnya rugirugi belitan dan menurunnya efisiensi. Gelombang harmonisa juga berdampak terhadap meningkatnya vibrasi generator sehingga menambah besar rugi mekanik dan pada akhirnya menurunkan efisiensi generator. Sementara itu harmonisa pada transformator akan mengakibatkan bertambahnya rugi-rugi inti (histerisis dan arus pusar) serta rugi-rugi simpangan magnetik (stray magnetic losses) dan tembaga pada belitan [12], [13], [14]. Dampak buruk harmonisa terhadap alat-alat ukur yang terpasang pada sistem kelistrikan adalah terjadinya kesalahan pengukuran jika alat-alat ukur yang terpasang tidak bekerja dengan baik untuk gelombang tegangan atau arus yang mengandung harmonisa.

Dampak buruk harmonisa terhadap sistem kelistrikan diantaranya mencakup munculnya arus netral, bertambahnya rugi-rugi pada kawat serta pengaruh terhadap faktor daya (power factor, disingat pf). Aturan keseimbangan fasa yang menghasilkan arus netral nol tidak berlaku untuk gelombang arus nonsinusodial yang mengandung gelombang harmonisa. Artinya dengan beban per fasa yang seimbang sekalipun, selama terdapat harmonisa arus dari beban non-linier maka arus di kawat netral akan tetap ada [12]. Adapun pengaruh harmonisa pada kawat penghantar secara umum adalah dengan meningkatkan rugi-rugi tembaga dan efek kulit (skin effect). Sementara itu harmonisa juga mengakibatkan penurunan faktor daya yang dinyatakan dalam besaran true power factor (TPF) [13].

Mempertimbangkan banyaknya dampak buruk dari gelombang harmonisa tersebut di atas maka berbagai upaya dilakukan untuk mengatasinya. Secara umum 
cara untuk mengatasi dampak buruk gelombang harmonisa dapat dilakukan melalui penggunaan pasif filter, aktif filter serta transformator penggeser fasa. Metode pasif filter relatif lebih murah, rangkaiannya relatif sederhana serta dapat sekaligus berfungsi untuk perbaikan faktor daya. Namun untuk melakukan eliminasi harmonisa dengan orde-orde frekuensi tertentu diperlukan analisis berbantuan komputer untuk memperoleh spektrumnya. Metode aktif filter memiliki kelebihan dari aspek jangkauan eliminasi harmonisa yang lebih luas/lebar, kemampuan untuk sekaligus berperan sebagai kompensasi daya rekatif serta sesuai dengan standar IEEE 519-1992. Kekurangannya terletak pada biaya yang lebih mahal, khususnya untuk aktif filter tipe serial, serta memiliki rangkaian yang lebih kompleks dan rumit. Metode transformator penggeser fasa sangat cocok untuk eliminasi harmonisa yang diakibatkan oleh beban non-linier berupa VSD atau catu daya dc yang menggunakan konverter berupa penyearah tiga-fasa [15].

\section{Metodologi Kajian Pengaruh Harmonisa Arus Beban Non-Linier Terhadap Hasil Pengukuran Energi Listrik}

Untuk melakukan kajian mengenai pengaruh harmonisa arus yang muncul sebagai penggunaan beban-beban non-linier terhadap pengukuran pemakaian atau konsumsi energi listrik dengan kWhmeter analog maka perlu dilakukan dua uji laboratorium yang berbeda. Uji laboratorium pertama dilakukan untuk mengukur konsumsi energi listrik pada sistem kelistrikan dengan beban linier yang tidak menghasilkan gelombang harmonisa arus. Uji laboratorium yang kedua dilakukan untuk mengukur konsumsi energi listrik pada sistem kelistrikan dengan beban non-linier yang menghasilkan gelombang harmonisa arus. Pengukuran konsumsi energi listrik pada dua kondisi uji laboratorium yang berbeda ini dilakukan dengan kWhmeter analog dan PQA dimana hasil pengukuran oleh PQA digunakan sebagai acuan. Selisih antara pengukuran dengan kWhmeter dan PQA merupakan kesalahan pengukurannya. Beban linier yang digunakan dapat berupa lampu pijar (beban resistif) dan/atau motor listrik tanpa penggerak/pengendali putaran. Sementara itu, beban non-linier yang akan digunakan dapat berupa lampu hemat energi (CFL) serta penyearah dioda. Selain untuk mengukur konsumsi energi listrik, PQA dapat juga digunakan untuk mengukur gelombang harmonisa arus yang dihasilkan oleh beban non-linier. Sistem kelistrikan yang digunakan dalam uji laboratorium ini adalah sistem kelistrikan satu-fasa sebagai representasi sistem kelistrikan rumah tangga dan sistem kelistrikan tiga-fasa sebagai representasi sistem kelistrikan industri atau gedung-gedung perkantoran dan komersial. Secara umum, blok diagram uji laboratorium tersebut di atas adalah sebagaimana ditunjukkan oleh Gambar 1 di bawah ini.

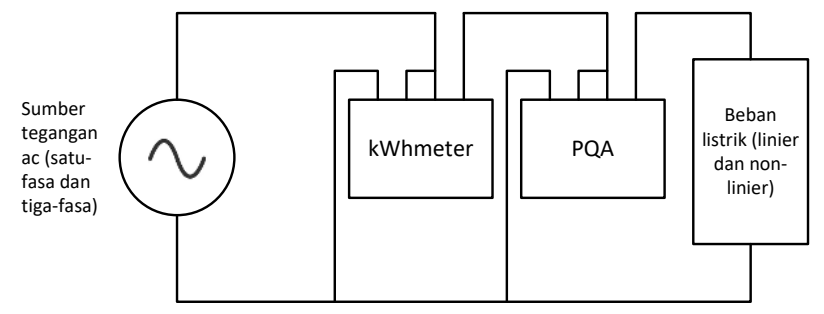

Gambar 1. Blok diagram rangkaian uji laboratorium.

\section{Data dan Pembahasan}

\subsection{Uji Laboratorium Pengukuran Konsumsi Energi Untuk Sistem Kelistrikan Satu-Fasa.}

Uji laboratorium pengukuran konsumsi atau pemakaian energi untuk beban listrik satu-fasa dilakukan untuk dua jenis beban yaitu beban linier dan non-linier. Untuk beban linier digunakan resistor variable dan lampu pijar. Sedangkan untuk beban nonlinier digunakan resistor variable ditambah dengan penyearah satu-fasa dan lampu LED. Pada kedua jenis beban, pengujian dilakukan selama 3 jam dengan perubahan/penambahan beban dilakukan setiap 1 jam sekali dan pengambilan data pemakaian energi dilakukan setiap 30 menit. Data pengujian pada Tabel 1 menunjukkan satu hal yang menarik yaitu pada saat beban yang terhubung adalah beban linier namun pengukuran terhadap gelombang arus menunjukkan adanya harmonisa dengan persentase rata-rata sebesar 4,6\%. Untuk sistem kelistrikan dengan beban linier maka nilai THD arus seharusnya $0 \%$ atau dengan kata lain tidak muncul gelombang harmonisa arus. Munculnya gelombang harmonisa arus dalam pengujian laboratorium ini adalah disebabkan oleh sumber tegangan yang digunakan bukan merupakan sumber tegangan sinusoidal murni yang ditunjukkan oleh nilai THD tegangan rata-rata sebesar $4,2 \%$. Jadi meskipun beban yang digunakan merupakan beban linier namun karena beban linier ini terhubung ke sumber tegangan yang mengandung harmonisa maka gelombang arus yang dihasilkan juga mengandung harmonisa. 
Tabel 1. Data uji laboratorium konsumsi energi untuk beban listrik satu-fasa.

\begin{tabular}{|c|c|c|c|c|c|c|c|}
\hline \multirow[t]{2}{*}{$\begin{array}{c}\text { Jenis } \\
\text { beban }\end{array}$} & \multirow[t]{2}{*}{$\begin{array}{c}\text { Nilai } \\
\text { beban } \\
(\mathrm{kW})\end{array}$} & \multicolumn{2}{|c|}{$\begin{array}{c}\text { Pengukuran } \\
\text { konsumsi energi } \\
\text { (kWh) }\end{array}$} & \multirow[t]{2}{*}{$\% \mathrm{THD}_{\mathrm{V}}$} & \multirow[t]{2}{*}{$\% \mathrm{THD}_{\mathrm{i}}$} & \multicolumn{2}{|c|}{$\begin{array}{c}\text { Selisih } \\
\text { pengukuran } \\
\text { konsumsi } \\
\text { energi }\end{array}$} \\
\hline & & kWhmeter & PQA & & & kWh & $\%$ \\
\hline \multirow{6}{*}{$\begin{array}{l}\text { Non- } \\
\text { linier }\end{array}$} & 1,6 & 0,74 & 0,795 & 5,0 & 87,4 & 0,055 & 6,92 \\
\hline & 1,6 & 1,66 & 1,604 & 5,0 & 89,1 & 0,056 & 3,49 \\
\hline & 2,0 & 1,05 & 1,010 & 5,4 & 85,6 & 0,040 & 3,96 \\
\hline & 2,0 & 1,09 & 1,030 & 5,2 & 87,3 & 0,060 & 5,83 \\
\hline & 2,1 & 1,07 & 1,045 & 5,5 & 84,2 & 0,025 & 2,39 \\
\hline & 2,1 & 1,11 & 1,059 & 5,7 & 86,3 & 0,051 & 4,82 \\
\hline \multirow{6}{*}{ Linier } & 0,9 & 0,46 & 0,452 & 4,4 & 5,1 & 0,008 & 1,77 \\
\hline & 0,9 & 0,46 & 0,449 & 4,4 & 5,1 & 0,011 & 2,45 \\
\hline & 1,5 & 0,80 & 0,756 & 4,3 & 4,7 & 0,044 & 5,82 \\
\hline & 1,5 & 0,80 & 0,769 & 4,0 & 4,4 & 0,031 & 4,03 \\
\hline & 2,2 & 1,16 & 1,111 & 4,1 & 4,3 & 0,049 & 4,41 \\
\hline & 2,2 & 1,255 & 1,207 & 4,1 & 4,0 & 0,048 & 3,98 \\
\hline
\end{tabular}

Data uji juga menunjukkan bahwa perubahan nilai pembebanan untuk jenis beban linier dan non-linier tidak secara signifikan mengubah nilai THD arus beban, sebagaimana ditunjukkan oleh Gambar 2 dan 3 di bawah. Untuk beban linier, saat nilai beban berubah dari $0,9 \mathrm{~kW}$ sampai dengan 2,2 kW maka THD arus berubah sedikit dari 5,1\% sampai dengan 4,2\%. Sementara untuk beban non-linier, saat nilai beban berubah dari 1,6 $\mathrm{kW}$ sampai dengan $2,1 \mathrm{~kW}$ maka THD arus berubah sedikit dari $88,3 \%$ menjadi $85,3 \%$.

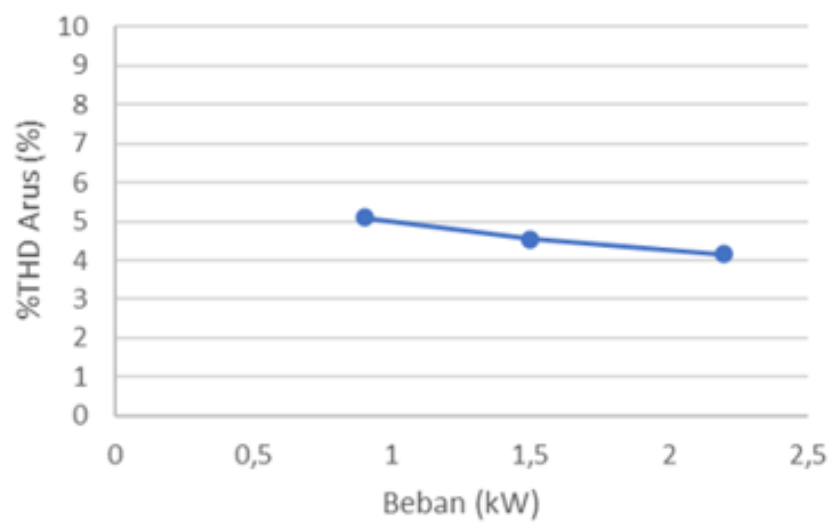

Gambar 2. Pengaruh pembebanan terhadap perubahan nilai THD pada sistem kelistrikan satu-fasa dengan beban linier.

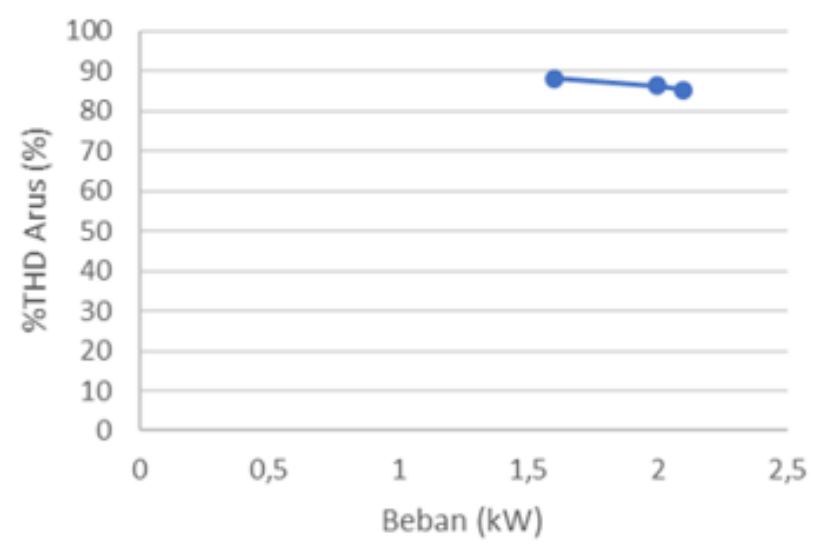

Gambar 3. Pengaruh pembebanan terhadap perubahan nilai THD pada sistem kelistrikan satu-fasa dengan beban non-linier.

Selanjutnya jika kita kaji pengaruh perubahan nilai THD arus terhadap pengukuran pemakaian energi listrik maka akan terlihat bahwa semakin besar nilai THD arus maka perbedaan hasil pengukuran pemakaian energi antara kWhmeter analog dan PQA juga akan semakin besar. Kesalahan pengukuran pemakaian energi, yang dihitung sebagai hasil pengukuran pemakaian energi antara kWhmeter analog dan PQA, naik dari rata-rata sebesar $3,7 \%$ pada nilai rata-rata THD sebesar $4,6 \%$ menjadi rata-rata sebesar $4,6 \%$ pada nilai rata-rata THD sebesar $86,7 \%$ sebagaimana ditunjukkan oleh Gambar 4 di bawah ini.

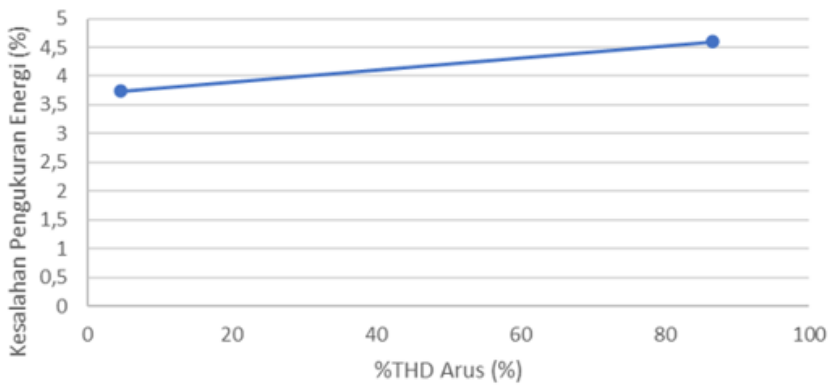

Gambar 4. Pengaruh perubahan nilai THD terhadap kesalahan pengukuran pemakaian energi pada sistem kelistrikan satu-fasa.

\subsection{Uji Laboratorium Pengukuran Konsumsi Energi Untuk Sistem Kelistrikan Tiga-Fasa.}

Uji laboratorium pengukuran konsumsi atau pemakaian energi untuk beban listrik tiga-fasa juga dilakukan untuk dua jenis beban yaitu beban linier dan non-linier. Untuk beban linier digunakan resistor 
variabel dan lampu pijar yang dipasang seimbang pada masing-masing fasa. Sedangkan untuk beban non-linier digunakan resistor variable ditambah dengan tiga buah penyearah satu-fasa dan lampu LED yang juga dipasang secara seimbang di masing-masing fasa. Jadi beban linier dan non-linier pada sistem kelistrikan tiga-fasa ini merupakan beban-beban seimbang. Pada kedua jenis beban, pengujian dilakukan selama 3 jam dengan perubahan/penambahan beban dilakukan setiap 1 jam sekali dan pengambilan data pemakaian energi dilakukan setiap 30 menit. Seperti halnya dalam pengujian sistem kelistrikan satu-fasa, data pengujian pada Tabel 2 menunjukkan bahwa meskipun beban yang digunakan merupakan beban linier namun muncul harmonisa arus rata-rata sebesar $4,1 \%$ yang disebabkan oleh sumber tegangan tiga-fasa yang mengandung harmonisa tegangan rata-rata sebesar 3,8\%.

Tabel 2. Data uji laboratorium konsumsi energi untuk beban listrik tiga-fasa.

\begin{tabular}{|c|c|c|c|c|c|c|c|}
\hline \multirow[t]{2}{*}{$\begin{array}{c}\text { Jenis } \\
\text { beban }\end{array}$} & \multirow[t]{2}{*}{$\begin{array}{c}\text { Nilai } \\
\text { beban } \\
(\mathrm{kW})\end{array}$} & \multicolumn{2}{|c|}{$\begin{array}{c}\text { Pengukuran } \\
\text { konsumsi energi } \\
(\mathbf{k W h})\end{array}$} & \multirow[t]{2}{*}{$\% \mathrm{THD}$} & \multirow[t]{2}{*}{$\% \mathrm{THD}_{\mathrm{I}}$} & \multicolumn{2}{|c|}{$\begin{array}{c}\text { Selisih } \\
\text { pengukuran } \\
\text { konsumsi } \\
\text { energi }\end{array}$} \\
\hline & & kWhmeter & $\mathrm{PQA}$ & & & kWh & $\%$ \\
\hline \multirow{6}{*}{$\begin{array}{l}\text { Non- } \\
\text { Linier }\end{array}$} & 1,3 & 0,70 & 0,649 & 3,1 & 107,5 & 0,051 & 7,86 \\
\hline & 1,3 & 0,70 & 0,649 & 3,0 & 109,9 & 0,051 & 7,86 \\
\hline & 2,3 & 1,21 & 1,123 & 3,1 & 113,3 & 0,087 & 7,75 \\
\hline & 2,3 & 1,22 & 1,130 & 3,1 & 114,0 & 0,090 & 7,96 \\
\hline & 3,0 & 1,61 & 1,496 & 3,6 & 111,9 & 0,114 & 7,62 \\
\hline & 3,0 & 1,61 & 1,491 & 3,5 & 110,7 & 0,119 & 7,98 \\
\hline \multirow{6}{*}{ Linier } & 4,1 & 2,13 & 2,069 & 4,2 & 4,6 & 0,061 & 2,95 \\
\hline & 4,1 & 2,17 & 2,040 & 3,9 & 4,3 & 0,130 & 6,37 \\
\hline & 6,0 & 3,27 & 3,038 & 3,5 & 3,8 & 0,232 & 7,64 \\
\hline & 6,0 & 3,18 & 2,984 & 3,7 & 4,0 & 0,196 & 6,57 \\
\hline & 9,9 & 5,31 & 4,925 & 3,7 & 3,9 & 0,385 & 7,82 \\
\hline & 9,9 & 5,19 & 4,862 & 4,0 & 4,1 & 0,328 & 6,75 \\
\hline
\end{tabular}

Data uji pada Tabel 2 juga menunjukkan bahwa pada sistem kelistrikan tiga-fasa perubahan nilai pembebanan untuk jenis beban linier dan non-linier tidak secara signifikan mengubah nilai THD arus beban, sebagaimana ditunjukkan oleh Gambar 5 dan 6 di bawah. Untuk beban linier, saat nilai beban berubah dari 4,1 kW sampai dengan 9,9 kW maka THD arus berubah sedikit dari $4,5 \%$ sampai dengan $4,0 \%$. Sementara untuk beban non-linier, saat nilai beban berubah dari 1,3 $\mathrm{kW}$ sampai dengan 3,0 kW maka THD arus berubah sedikit dari 108,7\% menjadi 111,8\%.

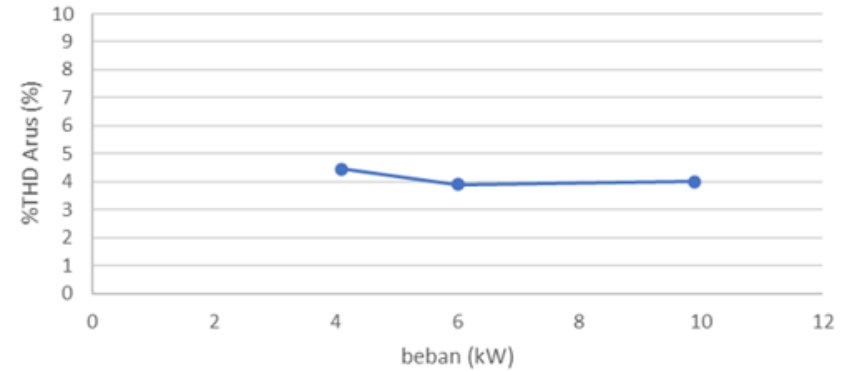

Gambar 5. Pengaruh pembebanan terhadap perubahan nilai THD pada sistem kelistrikan tiga-fasa dengan beban linier.

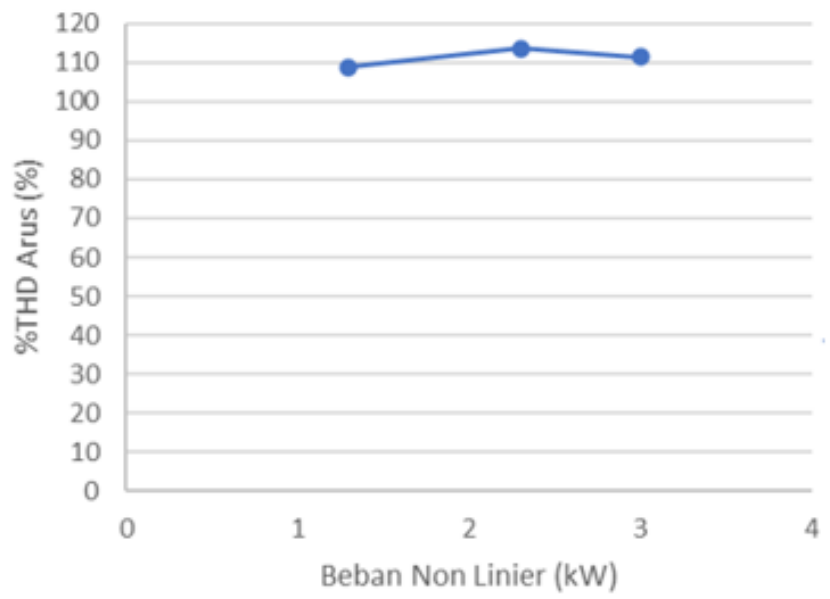

Gambar 6. Pengaruh pembebanan terhadap perubahan nilai THD pada sistem kelistrikan tiga-fasa dengan beban non-linier.

Selanjutnya jika kita cermati pengaruh perubahan nilai THD arus terhadap pengukuran pemakaian energi listrik maka akan terlihat bahwa semakin besar nilai THD arus maka perbedaan hasil pengukuran pemakaian energi antara kWhmeter analog dan PQA juga akan semakin besar. Kesalahan pengukuran pemakaian energi, yang dihitung sebagai hasil pengukuran pemakaian energi antara kWhmeter analog dan PQA, naik dari rata-rata sebesar $6,4 \%$ pada nilai rata-rata THD sebesar $4,1 \%$ menjadi rata-rata sebesar $7,8 \%$ pada nilai rata-rata THD sebesar $111,2 \%$ sebagaimana ditunjukkan oleh Gambar 7 di bawah ini. 


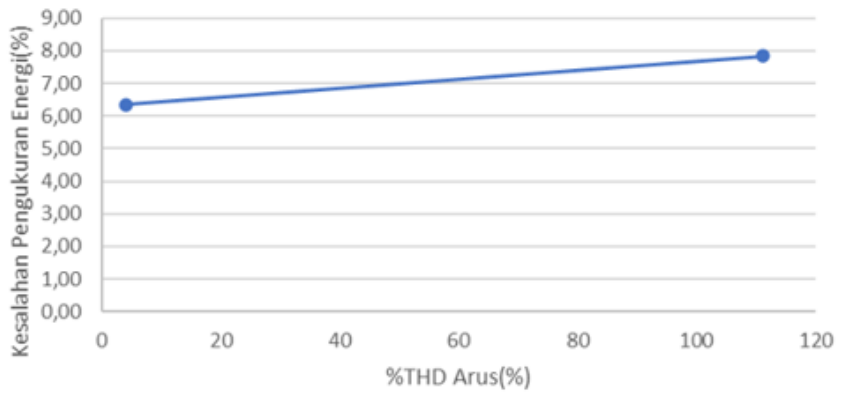

Gambar 7. Pengaruh pembebanan terhadap perubahan nilai THD pada sistem kelistrikan tiga-fasa dengan beban non-linier.

Jika kita bandingkan kesalahan pengukuran pemakaian energi listrik oleh kWhmeter analog yang diakibatkan oleh adanya gelombang harmonisa arus untuk sistem kelistrikan satu-fasa dan tiga-fasa maka akan terlihat bahwa tingkat kesalahan pengukurannya akan lebih besar pada sistem kelistrikan tiga-fasa

\section{Kesimpulan}

Berdasarkan hasil analisis terhadap data uji laboratorium, dapat disimpulkan bahwa:

1. Harmonisa memiliki dampak/pengaruh terhadap kesalahan pengukuran pemakaian energi oleh kWhmeter analog. Meski tidak meningkatkan kesalahan pengukuran secara signifikan namun secara umum semakin tinggi kandungan harmonisa arus, yang ditunjukkan oleh semakin tingginya nilai persentase THD arus, maka akan semakin tinggi pula tingkat kesalahan pengukuran pemakaian energi listrik oleh $\mathrm{kWhmeter}$ analog.

2. Pengaruh harmonisa terhadap kesalahan pengukuran pemakaian energi oleh kWhmeter analog lebih signifikan untuk sistem kelistrikan tiga-fasa jika dibandingkan dengan sistem kelistrikan satu-fasa.

\section{Ucapan Terima Kasih}

Penulis menyampaikan ucapan terima kasih dan penghargaan kepada Pusat Penelitian dan Pengabdian Masyarakat (P3M) Politkenik Negeri Bandung yang telah memberikan kesempatan dan kepercayaan untuk mengelola kegiatan penelitian ini melalui skema Penelitian Mandiri. Penulis juga menyampaikan ucapan terima kasih kepada Gilang Pamungkas, mahasiswa Program Studi D3 Teknik Konversi Energi, Politeknik Negeri Bandung atas bantuannya dalam melakukan uji laboratorium.

\section{DAFTAR PUSTAKA}

1. Robak, S., \& et. al. (2016). Variable Speed Drive (VSD) - Toward Modern Industry and Electricity Power System. Przeglad Elektrotechniczny.

2. Saidur, R., \& et. al. (2012). Applications of Variable Speed Drive in Electrical Motor energy Savings. (Renewable and Sustainalbe Energy Review).

3. Z. Wei, N. R. Watson, S. Member, and L. P. Frater (2008). Modelling of Compact Fluorescent Lamps. pp. 1-6.

4. J. Molina and L. Sainz (2014). Model of Electronic Ballast Compact Fluorescent Lamps. IEEE Trans. Power Deliv., vol. 29, no. 3, pp. 1363-1371.

5. J. Molina and L. Sainz (2014). Compact Fluorescent Lamp Modeling for Large- Scale Harmonic Penetration Studies. IEEE Trans. Power Deliv., vol. 8977, no. c, pp. 1-9.

6. S.A. Papathanassiou, G.A. Vokas, M. P. Papadopoulos (1995). Use of Power Electronic Converters in Wind Turbines and Photovoltaic Generators. Proceedings of the IEEE International Symposium on Industrial Electronics. Volume: 1.

7. M. H. Rashid (2011), Power electronics handbook : devices, circuits, and applications, Third Edition ed., Burlington: Elsevier Inc.

8. Harrison, A. (2010). The Effect of Harmonics on Power Quality and Energy Efficiency. Dublin: Dublin Institute of Technology.

9. Pinyol, R. (2015). Harmonics: Causes, Effects and Minimization. Barcelona: Salicru.

10. Bambiso, S. and Kusakana, K. (2018). Life Cycle Cost Comparison between Motor Equipped with Speed Drive and Dampers for Pumps and Fans. IEEE PES/IAS Power Africa, pp. 931-936.

11. M. A. Patel, A. R. Patel, D. R. Vyas, K. M. Patel (2009). Use of PWM Techniques for Power Quality Improvement. International Journal of Recent Trends in Engineering, Vol. 1, No. 4.

12. Kastawan, I M. W. (2017). Peningkatan Rugi-Rugi Transformator Daya Akibat Pembebanan NonLinier. Prosiding Seminar Nasional Teknologi 
Elektro Terapan. Politeknik Negeri Malang, Indonesia.

13. Davudi, M., Torabzad, S., and Ojaghi, B. Analysis of Harmonics and Harmonics Mitigation Methods in Distribution System. Australian Journal of Basic and Applied Science, Vol. 5, pp. 996-1005.

14. Kastawan, I M. W. (2018). Effects of Load Current Harmonics on Vibration of Three-phase Generator. Proceeding of Annual Applied Science and Engineering Conference (AASEC). UPI, Bandung, Indoensia.

15. Kastawan, I M. W. (2020). Design of PhaseShifting Transformer Based on Simulink Matlab Simulation. International Journal of Applied Technology Research. Vol. 1, No. 2, pp. 148-162. 